\title{
PLACING ACCOUNTING AMONG SCIENCES
}

\author{
Mihai Deju \\ "Vasile Alecsandri” University of Bacău \\ dejumihai@yahoo.com
}

Petrică Stoica

Romanian Court of Accounts, Bacău County Chamber of Accounts

stc_petrica@yahoo.com

\begin{abstract}
Framing accounting as a science has been carried out in close connection with the development of knowledge in this field and with the meaning given to this concept of "science". Recognizing accounting as scientific field by specialists is due to the fact that it features a combination of accounting theory and methods for the development and application of these theories. Accounting is a scientific discipline in the social sciences because: it is a creation of the human being in response to practical needs; it reflects phenomena, activities and social facts; it addresses various groups of users (managers, bankers, shareholders, employees, tax bodies, etc.) which are an integral part of society; it offers information necessary to decisionmaking, most of the times with impact on the behaviour of individuals; it is influenced by the economic, social, legal and political environment, that is by social phenomena.
\end{abstract}

\section{Keywords}

accounting; scientific; domain; theory; paradigm; evolution

\section{JEF Classification}

M41

Nowadays accounting is regarded as an independent scientific discipline, with its own status in the family of social sciences, the system of economic sciences. The evolution of accounting as a social practice is linked to the development of the human being as an economic being.

The oldest known form of accounting was memorial accounting, by which paycommitments and receivables were recorded chronologically, and were considered distinct businesses.

Later on, the simple-entry bookkeeping appeared, moment recorded by the author of the compendium "The sum of arithmetic, geometry, proportioni et proportionalita", Luca Paciolo (Rusu, 1991) in 1494. The author did not invent a new accounting method, but presented in detail the way of application and the rules of the double entry bookkeeping. Through this work, the author was the first to integrate accounting in the family of sciences using mathematics.

Framing accounting as a science has been carried out in close connection with the development of knowledge in this field and with the meaning given to this concept of "science". As the double-entry bookkeeping was applied in the Western Europe and the accounting literature and teaching were applied, the concerns on the scientific status of accounting increased.

Recognizing accounting as scientific field by specialists is due to the fact that it features a combination of accounting theory and methods for the development and application of these theories. Accounting is a scientific discipline in the social sciences because:

$>$ it is a creation of the human being in response to practical needs;

$>$ it reflects phenomena, activities and social facts; 
$>$ it addresses various groups of users (managers, bankers, shareholders, employees, tax bodies, etc. ) which are an integral part of society;

$>$ it offers information necessary to decision-making, most of the times with impact on the behaviour of individuals;

$>$ it is influenced by the economic, social, legal and political environment, that is by social phenomena.

J. B. Say considered accounting "the real economic science", due to the contribution to the emphasis of flows and the circuit of exchanges between economic agents, being concerned at the same time about the measurement, respectively the quantification of their size (Klee, 1992).

In the economic and judicial sense, professor Dumitru Rusu has come to the conclusion that the subject of accounting is "the assembly of movements of values that can be expressed in money in a small or great extent as well as the economic and judicial relationships which take birth between the units of the national economy and cause monetary settlements between them; the calculations of accounting reflect a sudden movement and transformation of economic means as well as resources in their order of formation and according to their destination in the process of reproduction" (Rusu, 1980).

Professor Bernard Colasse argues that between geography and accounting there is a relationship of epistemological affinities, both disciplines affect the information needs of the human being and they face the problem of correspondence between the real space (the entity, i.e. its territory) and the space described (the accounting plan, respectively the map). In the case of accounting, he considered that the subject constitutes at the same time an object of knowledge. As compared with physical or natural phenomena, the phenomena observed by accounting depend on the human behaviour. Accounting depends on the socio-economic organisation where it operates, and, in turn, acts on this organisation.

The scientific status of accounting is connected to the existence of one or more theories in accounting. According to Thomas S. Kuhn ${ }^{1}$, in any scientific discipline which has reached maturity (called "normal science"), the research is based on one or more paradigms. In his opinion, paradigms or theories are those "scientific accomplishments universally recognized that, for a period, offer model problems and solutions to a community of practitioners (of science)" (Kuhn, 1976).

The members of a disciplinary scientific community have in common one or more paradigms, i.e. a "disciplinary matrix" that provides a relative wholeness of their professional communication (the language of communication) and a relative consensus on their professional judgments. The question is: To what extent do we identify the existence of paradigms in accounting?

The recent decades have been marked by the increasing concerns of several authors to develop and validate a theory of accounting, so that, in time, to shape up the existence of several paradigms in accounting. Thus, professors B. Esnault and Ch. Hoarau have identified five fundamental paradigms in accounting (Ionaşcu, 1997):

- The inductive approach: the elaboration of the accounting theory is made by the generalization of the observations provided by accounting practices;

- The deductive approach: it assumes prior definition of the objectives of which there are deducted postulates, conventions, methods and rules for accounting;

- The predictive approach: it consists in testing accounting methods and rules, depending on their capacity of prediction of events, thus facilitating the decisionmaking;

\footnotetext{
${ }^{1}$ He graduaded Harvard University where he studied physics. He was professor of the history of science at Berkeley University of California, Princeton University and at the Institute of Technology in Massachusetts (MIT).
} 
- The behavioural or psychological approach: it studies the individual user's reactions at the time of publication of accounting information and it focuses on accounting information relevance to decision-making;

- The economic approach of information: it sees accounting information as an economic asset. The nature and the quantity of published information are dependant on the offer of accounting information producers and the users' demand.

Another author, Henning Kirkegaard (1988), shows that the evolution of accounting consists in the transition from one paradigm to another (Cossu, 1995). He identified three paradigms in accounting that show in fact the evolution of the accounting model:

- The first paradigm or the treasurer's paradigm: according to which the treasurer as unique actor, must answer three questions: where have the money come from? Where will the money go? What is the money stock? This model of accounting (cash accounting) corresponds to the economy in which payments are made only in cash.

- The second paradigm or the accountant's paradigm: it appeared together with the development of the accounting language that includes logics, which allows the transfer of a service, as well as the transfer of the appropriate payment to be made in two different moments. In order to be complete, the second paradigm includes the first one. The accounting model requires two actors, the accountant who has to justify the origin and destination of money, and the treasurer that is limited to the context of monetary flows.

- The third paradigm or the administrator's paradigm: in an uncertain environment, administrators put the accounting information on the first place when making decisions. The administrator's paradigm has three actors (the treasurer, the accountant and the administrator) and has three important moments:

- when the decision is taken, but not performed;

- when the decision is made, with the possibility of finding discrepancies at the moment of its performance;

- when the performed operation is paid, with the possibility of determining deviations from the time of payment.

Methodologically, it is based on the merger between accrual accounting and traditional double-entry accounting. The acceptance of the new paradigm could generate an information system for the management of organizations, that is, an accounting model oriented to towards the satisfaction of all accounting information users. The presentation of the evolution of accounting as a succession of paradigms shows us that the history of accounting may be regarded as the history of competitions between competing paradigms.

By reference to the exact sciences, this diversity of approaches would mean a lack of maturity of accounting as a scientific discipline, so accounting would be in a prescientific stage.

T. S. Kuhn admits that, in a given field, there can be one or a lot of paradigms: "scientists would say that they share a theory or a lot of theories" (Kuhn, 1976). The existence of paradigms in accounting confirms its status as a mature scientific discipline.

Another aspect related to the scientific status of accounting is the impact of theoretical researches on accounting practices. The role of practitioners and of professional organisations remain important in the development of accounting and its adapting it to the environment in which it operates; in recent decades has increased the importance of research in the field of accounting, research generally led by the academic environment. 
Current accounting research methodology is based on the statistical-mathematical tool and on the methods used by other social sciences, making accounting "an increasingly scientific technique, what in the philosophy of science is called a techno science" (Colasse, 1993), which is a technique in symbiosis with science.

Accounting research is relatively recent and is growing differently from one country to another. In the USA, the first body which has set out to bring together the efforts of teachers and researchers in the field of accounting, considered as global referential, was created in 1916 and named "The American Accounting Association" (AAA). In Romania, the start was in 1994 by creating "The Romanian Accounting Association” (ARC).

The accounting research carried out in universities and directed by such bodies makes us witness the shaping of scientific communities or disciplinary groups working in the field of accounting. Similar to the other scientific disciplines, in the field of accounting as well, we can see a fundamental research, designed to analyze accounting as social, organizational and historical phenomenon, and an applied research that aims at improving the accounting tool depending on the realities of accounting practice. The existence of the two sides of the accounting research was identified by some Romanian authors who have named accounting as a "fundamental and applied science" (Demetrescu et al, 1979).

Moreover, Professor B. Colasse proposed the identification of a normative accounting research, motivated by the fact that accounting practices are based on accounting rules drawn up by the agencies of normalisation. These rules are preceded by studies and work that is by forms of normative or doctrinal research.

Accounting uses research methodologies that belong to the empirical sciences, as well as the methodologies of theoretical sciences, being a field opened to fundamental and applicative research.

As a field of social sciences, accounting is nowadays awarded by two families of sciences: Economics and Management Sciences.

Currently, in the accounting filed there is a way of organization that highlights two complementary aspects: on the one hand, accounting aims to provide information to external users (domain characteristic of financial accounting), and on the other hand, the information provided by accounting relates to internal users (it is the case of internal management accounting).

In perspective, accounting is seen as a true and fair view of the financial position, of performances and changes in the financial position of the company, becoming a useful database in underlying decisions, regardless of their nature. Contemporary accounting research does not develop no autarchically in relation to other areas of scientific knowledge or of the socio-economic context.

Accounting in the scientific knowledge (Ionaşcu, 2003) is a form of representation of an organisation, and the "art" of this representation is practiced by empowered persons, accounting professionals who have appropriate academic training. We see accounting as a management technique that allows the collection, processing and analysis of information relating to transactions and events of an entity.

In accounting there are recorded by specific techniques only the transactions and events which can be quantified monetarily, thus distinguishing the accounting reality. On the other hand, accounting is an information system that allows the production and dissemination of information for decision making.

Currently, the scientific status of accounting cannot be certified unitarily, but most authors recognize accounting as a scientific field, because it has a set of accounting theories and methods for developing and applying these theories.

Since the early part of the 19th century, accounting has been regarded by some authors as an economic science. The close link between economics and accounting is explained by the fact that the latter should reflect, in a conventional manner, all the 
economic facts that affect the organisation, i.e. the facts relating to the production, distribution and consumption of wealth, being in this sense "the safest method of economic observation".

The status of accounting as a science of human action is given by the fact that management problems originate in human actions, and on the basis of the concept of human action there is the assumption that "human reason plays a role in each action" (Kirzner, 1996).

Scientifically, it should be noted that Romania has a small community of researchers in accounting in relation to other countries. Accounting research is carried out largely in universities, under the form of doctorate studies.

The results of scientific work are the product of personal initiatives because the forms of institutionalised accounting research are missing. Although some works of Romanian literature accounts may be considered documentary synthesis, by using the domestic and foreign bibliography, the original approaches, with an innovative role in the conceptual and methodological plan, they are still insignificant.

Written communication in accounting is carried out by specialized newspapers and journals (The Journal of Public Finances and Accounting, Company's management and accounting, Business Accounting and Audit, The Economist, Capital, Economic Truth), edited by various factors interested in accounting, but which promote, more often than not, a literature of commenting accounting rules.

As concerns the view of practitioners on accounting, we consider that it is mainly technical, based on accounting procedures provided by the legal rules, quite perishable (due to the very frequent changes) and dominated by fiscal influences.

In higher education we appreciate that there are two guidelines for approaching accounting as a discipline of study, situation resulting also from the way accounting is treated in university courses.

A first approach, as a succession of accounting entries, reduces accounting to the primary status of simple technique for recording economic-financial operations, without a guiding doctrine. Another approach to accounting is based on the pedagogical presentation of the company's accounting model, structuring operations in activities generating results in the form of monetary profit and revenue. We consider that this way of presentation better defines accounting as a scientific discipline.

Epistemologically, for most authors accounting remains a component of the economic science with a theoretical-applicative character and with a role of "recording economic phenomena and processes”.

There are different opinions among Romanian authors, as well, concerning the scientific positioning of accounting. For a large part, accounting continues to be classically defined as a scientific discipline in the system of economic sciences (Călin et al, 1997; Petriş, 2000), while for others it is "an information discipline (...), the only discipline that can provide financial information about an organization" (Caraiani \& Olimid, 2001). Another segment of authors consider that accounting is a "techno science", i.e. a technique fuelled by knowledge generated by the accounting practice and by the results of scientific research.

Accounting should be considered a mature discipline, with many theories, a component of management sciences, an approach resulted from a new replacing of social scientific disciplines.

The conceptual framework of accounting is defined by the Financial Accounting Standards Board (FASB) as "a coherent system of objectives and fundamental principles, interrelated, likely to lead to the formulation of solid rules and indicate the nature, role and limits of financial accounting and the financial statements.”

According to the professors Niculae Feleagă and Ion Ionaşcu, the conceptual framework of accounting "is a guide for the development of accounting rules and 
their interpretation. It is a support for processing the operations relating to transactions and events involved in the company's activity, which are not resolved by the rules.” (Feleagă \& Ionaşcu, 1998)

The local accounting system imposed since $1994^{2}$, has changed the basic concept with regard to the organisation of accounting, from a monist approach to a dualistic vision, dividing accounts in two sections: the general accounting, called also financial accounting, and management accounting.

In its evolution, accounting proved to be traditionally a cash accounting. Cash accounting does not make a distinction between the notions of expenses and payments and between the concepts of income and revenue. The accrual accounting records income the moment they are realized and expenses are charged as they are used, regardless of the date on which the effective payment or collection takes place.

In professor Feleagă's opinion, "cash accounting advanced accrual accounting. Moreover, nowadays, small businesses and most agents use, in one form or another, cash accounting.” (Feleagă, 1996)

Romanian accounting represented a "mixture" of cash accounting and accrual accounting, until early 1994 (being an accrual accounting when recording expenditure and cash accounting when recording revenue), and after this date it became a real accrual accounting.

The organisation of accounting in terms of harmonisation implies additional costs that Romanian companies will have to bear. To training costs there are added the costs for computerization in accordance with the International Standards of Accounting, as well as the costs for permanent consultancy and auditing of annual accounts (the consultancy and audit being carried out by different independent professionals).

Moreover, by the laws and regulations in force, some companies are required to carry out the annual financial audit of financial statements, when auditors express their opinion on the accuracy of financial statements. We wonder to what uses this opinion, whether it is favourable or not, and to whom is it useful? Accounting gives a new meaning to the practitioner, as the latter is no longer in a "convenient" position of performer, passing to the position of economic analyst.

Guessing what accounting will become a quite difficult intellectual exercise. In order to foresee the future accounting systems or techniques, we should anticipate primarily the economy of the future as a very important factor of accounting. As concerns the research on the economy of the future, the results are contradictory.

We believe that accounting research should not focus exclusively on improving the existing system, as there is the possibility that, in another country, various companies already experiment new methods of accounting.

\section{References}

Călin, O., Ristea, M., Văduva, I., Neamţu, H. (1997), Bazele contabilităţii, The Didactic and Pedagogical Publishing House, Bucharest.

Caraiani, C., Olimid, L. (coord.) (2001), Bazele contabilităţii, Second Edition, ASE Publishing House.

Colasse, B. (1993), Comptabilite generale, Fourth edition, The Economic Publishing House, Paris.

Demetrescu, C. G., Puchiţă, V., Possler, L., Voica, V. (1979), Contabilitatea, ştiinţa fundamentală şi aplicativă, Romanian Writing Publishing House, Craiova.

Feleagă, N. (1996), Controverse contabile, The Economic Publishing House, Bucharest.

\footnotetext{
${ }^{2}$ In accordance with the provisions of The Fourth Directive of the European Economic Community and International Standards of Accounting
} 
Feleagă, N., Ionaşcu, I. (1998), Tratat de contabilitate financiară, Vol. II, The Economic Publishing House, Bucharest.

Ionaşcu, I. (1997), Epistemologia contabilităţi, The Economic Publishing House, Bucharest.

Ionaşcu, I. (2003), Dinamica doctrinelor contabilitătii contemporane, Studii privind paradigmele şi practicile contabilităţii, The Economic Publishing House, Bucharest, 33-48.

Kikegaard, H. (1988), The future of management accounting - Draft paper, Copenagen Business University, quoted in Cossu, C. (1995), Melanges en l'honneur du Professeur Claude Perochon, Editions Foucher, Paris.

Kirzner, I. (1996), Perspectiva economică. Un studiu asupra istoriei gândirii economice, All Publishing House, Bucharest.

Klee, L. (1992), Image fidele et jeux d'image sur l'entreprise - reflection sur les rapports entre principes comptables et realite economique, Revue de droit comptable, 92-4.

Kuhn, T. S. (1976), Structura revoluţiilor stiintifice, Translation, Scientific and Encyclopedic Publishing House, Bucharest.

Petriş, R. (2000), Bazele contabilităţii: breviar, Gorun Publishing House, Iaşi.

Rusu, D. (1980), Bazele contabilităţii, Second edition, Didactic and Pedagogical Publishing House, Bucharest.

Rusu, D. (1991), Fra Luca di Borgo şi doctrinele contabilităţii în cultura economică românească, Junimea Publishing House, Iaşi. 